\title{
The Subject-Matter of Press Publishers' Related Rights Under Directive 2019/790 on Copyright and Related Rights in the Digital Single Market
}

\author{
Elżbieta Czarny-Drożdżejko (D)
}

Published online: 27 April 2020

(C) The Author(s) 2020

\begin{abstract}
The subject of this paper is the interpretation of the definition of a "press publication" contained in the new Directive 2019/790 on copyright and related rights in the Digital Single Market. The precise examination of particular aspects of this definition is important because the entities issuing publications defined as "press publications" obtain a new related right under the Directive. Thus, the definition constitutes the basis for constructing a monopoly of press publishers in relation to such forms of exploitation of press publications in the digital environment as reproduction and making available to the public. Therefore, this analysis assesses various problems arising from the interpretation of the above-mentioned definition, which indicates that this definition is far from unambivalent. It should also be emphasized that definitions of both the press and press publications as applied in various national legal systems for the purposes of administrative, civil or criminal law overlap, including in areas that are beyond the sphere of EU coordination. Hence, numerous interpretative issues, both in the EU legal system and in the systems of individual Member States, may be expected to arise in the future.
\end{abstract}

Keywords Intellectual property · Related rights · Press release · Directive 2019/790 on copyright in the digital single market

\section{Introduction}

On 26 March 2019 the new Directive 2019/790 on copyright in the Digital Single Market, which, inter alia, establishes new related rights for publishers of press publications, was finally adopted by the European Parliament. The Directive was

E. Czarny-Drożdżejko ( $\bowtie)$

Dr. hab.; Professor UPJPII, Pontifical University of John Paul II, Kraków, Poland e-mail: elzbieta.czarny_drozdzejko@upjp2.edu.pl 
approved on 17 April 2019 by the President of the EU Parliament and the Council, and sent for publication in the Official Journal. ${ }^{1}$

One of the fundamental reasons for formulating the Directive was to address problems related to the reproduction and making available to the public of press materials online. Another particular concern was the question of the fair distribution of income between publishers who make appropriate investments and organize the publishing process, on the one hand, and information society service providers, on the other hand. ${ }^{2}$ The discussed lack of a monopoly for press publishers with regard to their press publications led the European Commission to theorize that in the final analysis this may affect citizens' access to information. ${ }^{3}$ However, the establishment of a new related right raises justified concerns.

Despite numerous amendments, the definition of a press publication is likely to be contentious in every Member State of the European Union. In view of the fact that the notion "press publication" is already contained in the legal system of the EU, the CJEU will undoubtedly have to construe it uniformly for the purposes of Directive 2019/790 under consideration for all Member States. The diverse definitions of press or press publications which are binding in the individual Member States may or may not overlap with the new EU definition of "press release". Unfortunately, this overlap can also affect areas that are not subject to Community coordination. The definitions formulated in the French and Polish legal systems provide examples.

In the French system, "press publication" means any service using a written mode of dissemination of thought available to the general public or to specific categories of the public and appearing at regular intervals. "Online press services" have been defined separately as any online public communication service professionally edited by a natural or legal person who has editorial control of its content, consisting of the creation and making available to the public of original content of social interest and renewed regularly, the content being composed of current information presented directly and being simultaneously subjected to journalistic processing without consisting of a promotional tool or only being an accessory to industrial or commercial activity. ${ }^{4}$

In the Polish legal system, there is no definition of "press publication", yet there is a definition of "press". According to Art. 7(2)(1), the press means periodical publications that do not form a closed, homogeneous whole, appearing at least once a year, with a permanent title or name, current number and date, including, but not

\footnotetext{
${ }^{1}$ Directive (EU) 2019/790 of the European Parliament and of the Council of 17 April 2019 on copyright and related rights in the Digital Single Market and amending Directives 96/9/EC and 2001/29/EC (Text with EEA relevance), PE/51/2019/REV/1, OJ L 130, 17 May 2019, pp. 92-125.

2 Rapport (2018), p. 13. This report also points out that it is not justified that only certain entities that organize the production process (producers of phonograms, videograms, broadcasters) have related rights, while others (publishers) do not.

3 Proposal for a Directive of the European Parliament and of the Council on copyright in the Digital Single Market COM/2016/0593 final - 2016/0280 (COD), https://eur-lex.europa.eu/legal-content/PL/ TXT/?uri=CELEX\%3A52016PC0593 (accessed 16 April 2019).

4 Act of 1 August 1986, No. 86-897 reforming the legal system of the press, https://www.legifrance.gouv. fr/affichTexte.do?cidTexte=JORFTEXT000000687451\&fastPos=1\&fastReqId $=$ 1276233994\&categorieLien=cid\&oldAction=rechTexte (accessed 10 April 2019).
} 
limited to: daily newspapers and magazines, agency services, permanent telex messages, bulletins, radio and television programmes and film chronicles. The press shall also be any means of mass media, existing and emerging in the course of technological advancement, including broadcasting stations and television and radio broadcasting networks, publishing periodical publications by means of print, vision, sound or other dissemination techniques; the press also includes teams of people and individuals involved in journalistic activities. It transpires from the above that the definition of press may be approached from three perspectives. Firstly, in terms of the subject-matter; secondly, in terms of the means of mass communication; and, finally, in a subjective manner, such as a team of people involved in journalistic activity, i.e. creating, editing and preparing press materials. ${ }^{5}$ Arguably, in order for a particular medium to be considered as "press", it must fulfil all three definitions. On this account, the definition of press in the sense of subject-matter is crucial, and, according to this definition, for a given product to be regarded as press, it must fulfil the following requirements: (1) periodicity; (2) openness and diversity; (3) appearing at a maximum interval of up to one year; and (4) with a permanent title or name, current number and date.

However, it should be noted that the press, in the subjective meaning conceived of as a team of people and individuals, refers to the existence of a system of internal control and responsibility, thereby excluding blogs from the definition of press in Poland. However, a single isolated order issued by the Court of Appeals in Łódź is worth noting, as it did not rule out such an interpretation. ${ }^{6}$

Clear differences between the above-mentioned definitions come to the fore. If we additionally take the EU definition into consideration, crucial problems with interpretation are bound to arise, not only with respect to the scope of the legal system which is expected to be harmonized in the Member States, but also with respect to the system that remains within the exclusive competence of the Member States.

Bearing in mind the wide range of problems concerning the issue of the new related rights of press publishers, this paper will only focus on the analysis of the definition of "press publication".

\section{Subject-Matter of the New Related Rights of Press Publishers}

The primary issue referring to the new related rights is the question of arrival at the precise definition of its subject-matter, i.e. press publication. Its definition was evaluated throughout the entire process of creating Directive 2019/790 and was eventually adopted by the EU Parliament. In the final text of Directive 2019/790 adopted by the EU Parliament, after a series of consultations with the EU Council,

"press publication" means a collection composed mainly of literary works of a journalistic nature, but which can also include other works or other subjectmatter, and which:

${ }^{5}$ Dobosz (2011), p. 70.

${ }^{6}$ Order of the Appeal Court in Łódź of 18 January 2013, I ACa 1031/12, LEX No. 1280424. 
(a) constitutes an individual item within a periodical or regularly updated publication under a single title, such as a newspaper or a general or special interest magazine;

(b) has the purpose of providing the general public with information related to news or other topics; and

(c) is published in any media under the initiative, editorial responsibility and control of a service provider.

Periodicals that are published for scientific or academic purposes, such as scientific journals, are not press publications for the purposes of this Directive.

When comparing this text with the Commission's proposal, it may be found that the requirement that a press publication must be a "fixation of a collection of literary works of a journalistic nature" has been removed. This is due to the fact that problems with the interpretation of this term were foreseen. ${ }^{7}$ The concept of fixation would lead to the assumption that the original medium of the press publication would have to be placed somewhere. On the other hand, regardless of whether the fixation were only of a material nature and whether a physical copy had to exist would be debatable. The objective of a press publication was also corrected, namely, at present the goal is to provide the public with current news. It was also emphasized that the medium itself, i.e. the means by which a given press publication is distributed, does not matter; it can be both a printed and a virtual publication, with an additional condition: the publication must fall under the control of a press publisher.

\section{Press Publication as a Collection of Works and Other Subject-Matter}

A press publication shall constitute a collection of literary works of a journalistic nature, but it may also include other works or subject-matter protected by copyright. Consequently, two problems arise in this case. Firstly, the amount of materials a press publication entails and, secondly, their correct proportion. With the only requirement being that it shall be a collection, it therefore cannot merely contain a single publication, and, furthermore, it should mainly consist of journalistic publications.

However, it has not been determined how many elements should form a press publication. ${ }^{8}$ Maybe, for a set to exist, two or three elements are enough, or maybe it is necessary to combine more elements. Of course, it is difficult to assess in advance the amount of materials necessary to constitute a set. However, this problem may arise in relation to small periodicals, which may contain two or three separate press materials. Nonetheless, it should be noted that since the press publication according to the definition - is stipulated to be a "collection", it automatically infers that various works and other subject-matter created by different authors must form such a collection. Arguably, publications consisting exclusively of materials

\footnotetext{
7 Bently and Smith (2016), p. 10 .

${ }^{8}$ Cf. van Eechoud (2017), p. 33.
} 
authored by one person must therefore be ruled out from the definition of the press publication.

For a collection to be defined as a press publication, it must consist mainly of journalistic works. The English version of Directive 2019/790 uses the term "mainly" instead of "mostly", which suggests that a simple majority of journalistic works does not suffice. Journalistic works must, in a decisive manner, dominate over the others, perhaps reaching as much as $70-80 \%$ of the total. However, the method of calculating the amount of journalistic works per se was not established. Perhaps the sheer number of materials, regardless of the length of a text or size of an image itself, will serve as a measure.

According to Directive 2019/790, the main elements a press publication must incorporate are literary works of a journalistic nature. Such a combination seems quite surprising, because very few journalistic works may be thought of as literary. ${ }^{9}$ Traditionally, only serial fiction (op-ed pieces) or novellas were considered literary genres. Currently, press genres are divided into informative, opinionative or a combination of both. Opinionative genres are usually considered literary and include, among others, problematic reportage, op-ed pieces, commentaries, reviews, essays, diaries, novels in episodes, and editorials. ${ }^{10}$ It seems, however, that in order to interpret this term, reference must be made to the Berne Convention, which distinguishes, inter alia, literary works such as books, pamphlets and other writings. It therefore appears that the EU legislators had in mind this type of work. If we accept such an interpretation, the term "literary works of a journalistic nature" should simply be translated as journalistic textual works. Nonetheless, the Berne Convention does not explain how this concept should be understood. Moreover, in the first version of the Convention from 1886, journalistic materials were not considered literary works and were excluded from copyright protection since they were regarded as craft works. Throughout the course of time, certain journalistic works (op-ed pieces and novellas) obtained copyright protection as literary works (Paris revision from 1896), and nowadays they enjoy copyright protection as textual works. Due to treating journalistic materials as a kind of craft, the right of reproduction by the press was initially interpreted very broadly and only in later versions of the Berne Convention was it narrowed down. ${ }^{11}$

Thus, most doubts will arise on the basis of the requirement for the works incorporated in the press publication to be of a "journalistic nature". The aforementioned wording is not clear. ${ }^{12}$ For the purposes of the provisions on the protection of personal data, the term "processing of personal data solely for journalistic purposes" was introduced, as an exception to the scope of application of the previous Directive 2019/790 and, currently, the Regulation on the protection of

\footnotetext{
9 See Wolny-Zmorzyński and Kaliszewski (2014), p. 11 et seq.; Czarny-Drożdżejko (2016), p. 82 et seq.

${ }^{10}$ In this way Wolny-Zmorzyński and Kaliszewski (2014), p. 26.

11 See Michalski (1972), p. 18 et seq.; Czarny-Drożdżejko (2016), p. 82 et seq.; Ricketson and Ginsburg (2006), p. 796 et seq.

12 Van Eechoud (2017), p. 34.
} 
personal data. ${ }^{13}$ The CJEU interprets the purpose of "journalistic activity" as disclosure to the public of information, opinions or ideas irrespective of the medium that is used to transmit them. ${ }^{14}$ Therefore, a definite boundary between journalistic and non-journalistic activities was not introduced. This case concerned the dissemination of tax data by printing such data in a magazine, which indeed published articles although its main purpose was to provide tax information, including information on taxpayers. Such information was also disseminated using a text-messaging system. In such a case, it is impossible to consider such information as a journalistic work. In another judgment, the CJEU expressly recognized that the activity of search engines is not a journalistic activity. ${ }^{15}$ The CJEU assumed that "it should be pointed out that the processing of personal data carried out in the context of the activity of a search engine can be distinguished from and is additional to that carried out by publishers of websites, consisting in loading those data on an internet page". The CJEU further decided that

the processing by the publisher of a web page consisting in the publication of information relating to an individual may, in some circumstances, be carried out "solely for journalistic purposes" and thus benefit, by virtue of Article 9 of Directive 95/46, from derogations from the requirements laid down by the directive, whereas that does not appear to be so in the case of the processing carried out by the operator of a search engine.

In a recent judgment, ${ }^{16}$ the CJEU stated that

Article 9 of Directive 95/46 must be interpreted as meaning that factual circumstances such as those of the case in the main proceedings, that is to say, the video recording of police officers in a police station, while a statement is being made, and the publication of that recorded video on a video website, on which users can send, watch and share videos, may constitute a processing of personal data solely for journalistic purposes, within the meaning of that provision, in so far as it is apparent from that video that the sole object of that recording and publication thereof is the disclosure of information, opinions or ideas to the public, this being a matter which it is for the referring court to determine. Moreover, in the statement of reasons for the judgment he stated that "journalistic activities" are those which have as their purpose the disclosure to the public of information, opinions or ideas, irrespective of the medium which is used to transmit them.[...] Thus, having regard to the caselaw of the Court, the fact that Mr Buivids is not a professional journalist does

\footnotetext{
13 Regulation 2016/679 of the European Parliament and of the Council of 27 April 2016 on the protection of natural persons with regard to the processing of personal data and on the free movement of such data, and repealing Directive 95/46/EC (General Data Protection Regulation), OJ L 119, 4 May 2016, pp. 1-88.

14 Judgment of 16 December 2008, C-73/07, Tietosuojavaltuutettu v Satakunnan Markkinapörssi Oy, Satamedia Oy, ECLI:EU:C:2008:727.

15 Judgment of 13 May 2014, C 131/12, Google Spain SL, Google Inc. v Agencia Española de Protección de Datos (AEPD), Mario Costeja González, ECLI:EU:C:2014:317.

16 Judgment of 14 February 2019, Case C-345/17, Sergejs Buivids v Datu valsts inspekcija, ECLI:EU:C:2019:122.
} 
not appear to be capable of excluding the possibility that the recording of the video in question and its publication on a video website, on which users can send, watch and share videos, may come within the scope of that provision.

In view of the foregoing, no clear indication of what constitutes journalistic purposes has been formulated. Most things disseminated on the internet are informing about facts or providing opinions. It can only be hoped that the concept of a "work of journalistic nature" for the purposes of Directive 2019/790 will be more rigorously interpreted than the concept of acting "for journalistic purposes" and that this construction - arguably - should relate to the concept of "journalist".

In Poland, a legal definition of a journalist describes him/her as "a person involved in the editing, creation or preparation of press materials, remaining in an employment relationship with the editors or conducting such activities on behalf of and to the benefit of the editorial office". ${ }^{17}$ A literary work of a journalistic nature would therefore be press material prepared by a person who remains in a strictly defined, civil law relationship with an editorial team. In turn, Art. 7(2)(4) of the Polish Press Law Act stipulates that press material "shall be any published or submitted to publication text or image of informative, journalistic, documentary or other [nature], regardless of the media means, types, forms, destination or authorship". In Poland, the definitions of a "journalist" and "press material" have not yet been the subject of in-depth consideration in court rulings.

The French legal system also provides a legal definition of a journalist; however, the definition is limited to the notion of a professional journalist. According to Arts. L. 7111-3 to L. 7111-5 of the French Labour Code, a professional journalist is any person whose main, regular and remunerated activity is founded on the practice of his/her profession in one or more press companies, daily publications and periodicals or press agencies, and which is the main source of income for this person. ${ }^{18}$ Equated with professional journalists are: the direct collaborators of editorial staff, copywriters-translators, stenographers-copywriters, copywriterscorrectors, reporters-designers, and reporters-photographers, excluding advertising agents and all those who only provide occasional collaboration. The French Labour Code also introduces the following conditions to determine whether a person is a professional journalist, with the first criterion being that journalism must be his/her primary, main occupation. For this reason, a university professor, a supplier of several photographs or a person who works fewer than 40 hours a month for a press publisher and is employed full-time at another company is not recognized as a journalist. ${ }^{19}$ The second condition concerns the source of income: it must be the primary source. The owner of a website on agricultural issues was acknowledged as a journalist, who hired employees to edit the website, and he himself provided a significant part of the materials posted there. He was recognized as a professional journalist precisely because the main source of income was obtained from the

\footnotetext{
${ }_{17}$ Article 7.2, point 5, Act of 26 January 1984. Press law, consolidated text, Dz.U.2018.1914.

18 Labour Code, https://www.legifrance.gouv.fr/affichCode.do?dateTexte=20100202\&cidTexte= LEGITEXT000006072050\&fastReqId=567293234\&fastPos=1\&oldAction=rechCodeArticle (accessed 10 April 2019).

${ }^{19}$ Debbasch et al. (2002), p. 448.
} 
publication of materials. ${ }^{20}$ The third condition concerns the workplace. A journalist may be employed in press or electronic media companies.

On the other hand, in the Italian legal system there is a distinction between professional journalists and publicists. A professional journalist permanently and exclusively performs this profession, while a publicist is a person who performs journalistic activity for payment at irregular intervals, does not have to be employed by a press publisher, and may be engaged in different professions as well. ${ }^{21}$ Professional journalists and publicists should be listed in the appropriate public register.

As transpires from the above, the definition of a "journalist" is not uniform across the systems of the Member States. However, it is also not known whether the journalistic nature of a written work is a result of the author being a journalist. In turn, the fact of publication in the press is certainly not enough, because even in the EU definition of "press publication" in the analyzed Directive 2019/790, it is pointed out that a publication may include both journalistic and other works. Perhaps the journalistic nature of the material will be related to the internal journalistic standards implemented by the press publisher, namely reliability, special diligence and objectivity, or the pursuit of a true presentation of a specific case.

It seems, therefore, that the construction of the wording of "journalistic nature" will be based on a certain intuition rather than on explicit criteria. However, this wording should arguably be related to "journalist", because only in this way will the journalist's position vis-à-vis the publisher be strengthened. Perhaps this would lead to an increase in employment based on the employment contract in this profession, since publishers would be obliged to publish mainly works of a journalistic nature in order to benefit from the privileges granted to them by Directive 2019/790.

As pointed out above, the term "literary works" will, arguably, imply a written form. It should be noted here, that in the literature, ${ }^{22}$ a work which serves only as a literary entertainment, i.e. novels and poetry, is excluded from the category of "journalistic works". However, assuming they fall outside the category of "literary works of a journalist nature", they may be considered as "other works or subjectmatter" referred to in the definition of a press publication. The only issue is the right balance between the first and the other two groups, which must definitely be in favour of the former. It is questionable whether a press publication can consist solely of "other works or subject-matter".

It should be assumed that "other works or subject-matter" may include works communicated by words and images. Within the definition of the press publication, the French report also granted protection to "audio, visual and graphic content,

\footnotetext{
20 Ibid., p. 449.

21 Act of 3 February 1963, No. 69 Organization of the profession of journalist, https://www. gazzettaufficiale.it/atto/serie_generale/caricaDettaglioAtto/originario?atto.dataPubblicazioneGazzetta= 1963-02-20\&atto.codiceRedazionale=063U0069\&elenco30giorni=false (accessed 16 April 2019).

22 Bently and Smith (2016), p. 10.
} 
including photography". ${ }^{23}$ In the final text of Directive 2019/790 adopted by the European Parliament, Recital 56 explicitly refers to photographs and videos that can be included in a press publication. Because of the development of online portals that also present non-literary works, it seems that depriving them of special rights in this area (a related right only applies to broadcasts), in comparison with the protection of what may be printed, would seem unfair.

The term "other works" used in the definition of a press publication may therefore include, for example, works that are not of a journalistic nature, photographs, audio-visual and auditory works. On the other hand, "other subject matter" may be previously unpublished work and critical or scientific publications.

In practice, it can be problematic whether this "other subject-matter" needs to be protected as intangible goods. Currently, in the French and Polish versions of Directive 2019/790, it has been clearly indicated that this is to be "protected" subject-matter. Yet, in the English and Italian versions, there is no such indication. It is debatable, however, whether there can be such subject-matter - intangible goods - that is not protected in the legal system at all. It is, therefore, necessary to qualify them as works, the subject-matter of related rights or, possibly, industrial property, due to the principle of numerus clausus of rights in intangible goods. Therefore, the Polish and French versions of Directive 2019/790 are, arguably, the correct ones. However, even when adopting such a narrow scope, the range of elements that consist of a press publication is very wide and indeterminate. ${ }^{24}$

During the work on the adoption of Directive 2019/790, the issue arose of possible protection of so-called snippets (i.e. fragments of either literary works of a journalistic nature, other works or subject-matter). Since the creation of a new related right would not have to be justified by originality but only by the financial expenditure made by the publisher, the right could also apply to snippets: the fragments usually used by search engines or press aggregates. ${ }^{25}$ The French report explicitly stated that the exclusion of snippets from protection would, in principle, result in the rights of publishers and news agencies to be dead letters. The snippets themselves were defined in the above-mentioned report in a functional way, i.e. as fragments that void the necessity to read the entire press material. Their protection was justified by the magnitude of their use by new actors in the dissemination of journalistic productions. ${ }^{26}$ Currently Art. L. 211-3-1 of the French Intellectual Property Code $^{27}$ provides that

the beneficiaries of the rights granted upon article L. 218-2 cannot prohibit the use of isolated words or very short extracts from a press publication. This exception cannot affect the effectiveness of the rights granted upon article L.

218-2. This effectiveness is particularly affected when the use of very short

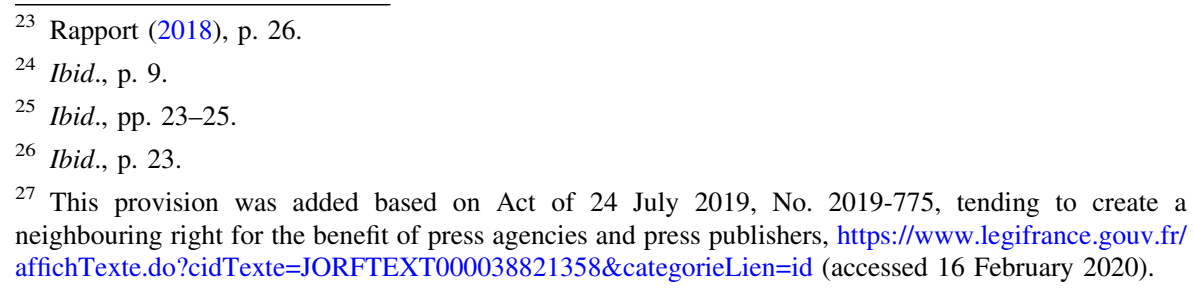


extracts replaces the press publication itself or exempts the reader from referring to it.

It is still not fully clear, however, whether the proposed protection would also refer to the summary of the press material.

Recital 58 of Directive 2019/790 states that

the use of press publications by information society service providers can consist of the use of entire publications or articles but also of parts of press publications. Such uses of parts of press publications have also gained economic relevance. At the same time, the use of individual words or very short extracts of press publications by information society service providers may not undermine the investments made by publishers of press publications in the production of content. Therefore, it is appropriate to provide that the use of individual words or very short extracts of press publications should not fall within the scope of the rights provided for in this Directive. Taking into account the massive aggregation and use of press publications by information society service providers, it is important that the exclusion of very short extracts be interpreted in such a way as not to affect the effectiveness of the rights provided for in this Directive.

It is evident that short fragments of press material should not be covered by the new publishing related rights. Unfortunately, this preclusion was not defined in a clear and precise way, leaving the question of the correct length of such a text unknown. If the exploitation of these short fragments shall not affect the effectiveness of publishers' rights, then the above preclusion will allow for the interpretation that a fragment must represent a length that does not satisfy the need to read the whole text. As a result, this may lead as far as to a ban on using even titles or links, if the core of the press material is amply disclosed in them. It seems, therefore, that the problem of the admissibility of the use of excerpts will still raise interpretational doubts, and the information society service providers themselves will not be able to assess in advance whether their conduct violates the related rights of the publisher of the press publication. Also, the problem whether using a short summary or description of the subject will infringe publishers' rights has not been solved.

With regard to the protection of fragments of press publications, such as the title or a lead, one may not, in principle, qualify them as literary works in the sense of even the most liberal copyright law, excluding only the French system, in which the copyright of the title itself is recognized. ${ }^{28}$ In turn, fragments cannot be "other subject-matter", as these must themselves be covered by separate legal protection.

\footnotetext{
28 Art. L. 112-3 Intellectual Property Code assumes copyright protection of titles. According to M. Vivant and J.M. Bruguière, however, it is hardly of consequence in this area. They state, for example, that the courts have accepted protection of such titles as Clochemerle, Felix the cat, and Angélique, although they did not accept protection of the Saveur title (taste) or Parle-moi d'amour. What is more, these authors are of the opinion that Art. L. 112-4 Intellectual Property Code does not preclude protection of the title being linked to the work to which it refers. In general, the title is protected if the expression was used for the first time. Originality in this case is similar to new products (Vivant and Bruguière (2015), pp. 188-183 and 286-287).
} 
In a situation where snippets serve only as short summaries of press materials, their protection on the grounds of derivative rights of another's works is questionable, because it would harm the freedom of expression. It should be noted that society cannot be prohibited from discussing or analyzing another's works, even when this goes beyond private or non-commercial uses. A significant difference exists between a comprehensive analysis of a literary work (analysis of a prescribed reading or a poetic work) and a short presentation of what the press material is about. Small volumes of press material do not require presentation of extensive descriptions to summarize them. Should such protection of short summaries be recognized, it would be a violation of the principle of freedom of expression, quashing the freedom to discuss the materials placed in the digital environment of all members of society. Consequently, such a decision would undermine the foundations of a democratic society. The protection of abstracts of press materials can also be excluded due to the fact that they can only present mere facts reported in press publications which have been excluded from protection as both works and the subject-matter of related rights. Therefore, snippets can arguably only be protected if they themselves meet the definition of a work, and thus display an individual character (originality).

Recital 57 of Directive 2019/790 stipulates that mere facts reported in press publications are not protected and, therefore, the exclusive rights of the publisher do not prevent anyone from being informed about current news. This is a clear reference both to the provisions included in national copyright systems (for example, in the Polish legal system in which the Act on Copyright and Related Rights $^{29}$ recognizes that copyright shall not cover simple press information), as well as to the principles already formed in legal doctrine and jurisprudence (for example, in France). ${ }^{30}$ It should be noted that the Berne Convention in Art. 2.8 also provides that "the protection of this Convention shall not apply to news of the day or to miscellaneous facts having the character of mere items of press information". It should be emphasized that in EU law no such explicit regulation exists. It is deemed unacceptable from the point of view of copyright to monopolize the circulation of information, among others, by press agencies. ${ }^{31}$

Lack of protection of mere press information refers only to the fact itself and not to its form. In a situation where this piece of news takes on an original form, it will be protected as both a work and the subject-matter of the new related right of press publishers. In the French legal system, so-called "raw information" must be new and not stand out by the form of its expression; ${ }^{32}$ thus being a piece of information that has not been enhanced by moulding it into an original form. It does not matter what content "mere news" presents - the message can be about sports, economics, politics or commerce. For example, copyright protection for a telegraph message,

\footnotetext{
29 Act of 4 February 1994, consolidated text Dz.U.2018.1191 with amendments.

30 See Debbasch et al. (2002), p. 774, note 2; Vivant and Bruguière (2016), p. 169; Blin et al. (1969), pp. 590-591.

31 See Czarny-Drożdżejko (2016), p. 19 et seq.; Michalski (1972), p. 56 et seq.

32 Blin et al. (1969), pp. 590-591.
} 
which can be a carrier of political, scientific or literary information, was denied. ${ }^{33}$ On the other hand, in a judgment of the Tribunal de Commerce in Paris, ${ }^{34}$ the protection of messages created by the French Press Agency was affirmed. In this case, however, there was a literal takeover of content of the message, including the quotes and spelling mistakes, on the general and freely available press website. The court considered that the messages had their original form and were therefore protected as works under the French Intellectual Property Code.

In the Polish legal system, Art. 4, point 4, of the Act on Copyright and Related Rights precludes the protection of simple press news. Opinions in the literature on the interpretation of "simple press news" are currently relatively scarce. According to J. Barta and R. Markiewicz, this preclusion applies only to pure, raw information, which is not a work "when information about facts is expressed in a standard, trivial, simple way". ${ }^{35}$ Arguably, Art. 4, point 4, of the Act is solely of an informative nature, because simple press information will never meet the definition of a work expressed in Art. 1.1 of the $\mathrm{Act}^{36}$ due to the lack of an individual character, thereby precluding protection. Article 4, point 4 , serves only as a kind of formal interpretation, an explanation and consequence of the accepted definition of the work. ${ }^{37}$

However, it should be emphasized that in Recital 57 of Directive 2017/790, it would have been better for the EU legislators to use only the expression "facts alone" without referring to a press publication. Simple, unenhanced information, without an original form, is not entitled to either copyright protection or as the subject-matter of the new related right of publishers of press publications. However, it should be remembered that the provisions of the Directive refer to the related rights of press publishers and are intended to exclude from protection only certain elements of press publications. By no means have EU legislators determined that only the mere facts contained in the press publication are not protected.

At the end of this part of this paper, it should be stated that in the case of the traditional press it is unlikely that there will be larger problems with including it in the definition of a press publication. However, there will be numerous doubts related to ordinary websites, because the wording "works of a journalistic nature" is not clear. The only indication provided by Directive 2019/790 can be found in Recital 56 , which states that blogs should not be included in press publications due to the lack of the initiative, editorial responsibility and control of a service provider, such as a news publisher. However, problems could be anticipated concerning all newsletters, websites run by entrepreneurs, sports clubs, schools, and even government and territorial administration, which should be excluded from the

\footnotetext{
33 Ibid., pp. 590-591.

34 Paris District Court for Commerce Matters, 5 February 2010, https://www.legalis.net/spip.php?page= jurisprudence-decision\&id_article=2873 (accessed 25 January 2016).

35 Barta and Markiewicz (2013), p. 71.

36 The subject-matter of copyright is any manifestation of creative activity of an individual character, established in any form, regardless of the value, purpose and manner of expression (work).

37 Zoll (1926), p. 27.
} 
category of press publications, even if they are edited by press offices or press spokespersons.

\section{Requirement for a Separate Entity of Press Publication}

The definition of a press publication also requires that it "constitutes an individual item within a periodical or regularly updated publication under a single title such as a newspaper or a general or special interest magazine". It was argued in the literature $^{38}$ that this premise could include dictionaries, Wikipedia and restaurant guides in the scope of press publications. It is not clearly stated in Directive 2019/790 how often a regular update of the press publication should take place. However, it is probable that given the entire definition of the press publication, including the fact that such collection should encompass mainly literary works of a journalistic nature, the aforementioned databases should be excluded from the category of press publications. It is not enough for a specific website to meet only one aspect of the definition of a press publication.

Nevertheless, it is important that only a specific item, which is determined in an established form, will be entitled to protection as the subject-matter of a new related right. It may change at certain regular periods of time or it may be constantly updated, which is the case with a press website. When it comes to the printed press, each concrete hard copy or its electronic version will be regarded as such subjectmatter of related rights. With regard to press portals, a press publication as the subject-matter of a related right will also assume a specific form, but its shape will change more often as a result of constant updates. However, this particular form will always be the subject-matter of a new related right for press publishers.

Whether the subject of press publications is general or specialist in nature is insignificant, as long as the next requirement of press publications, which is the transmission of current information or other topics, is met. Thus, even if the subject of the publication addresses a small group of potential recipients, it can be classified as a press publication. Specialist topics may refer to fishing, yachting, brokerage houses, etc. However, such publications cannot acquire the character of a scientific publication (academic papers).

At the same time, it should be pointed out that in the Polish system, in order for the medium to be included in the press category according to the Press Law already mentioned, the medium must be a periodical and published at least once a year. Periodicity should, in turn, mean the appearance of a publication at specific intervals. Thus, a problem related to the inclusion of online portals in the press category arises. ${ }^{39}$ The Supreme Court solved this issue by affirming that the periodicity of internet publications was demonstrated by the continuous and

\footnotetext{
38 Bently and Smith (2016), p. 11.

39 It should be noted that the Polish Press Law Act dates from 1984, i.e. from the time when there was no internet in Poland. Thus, at the time, this statute concerned only the printed press, radio and television. The online press in Poland appeared only in the mid-1990s. Due to the lack of a significant change in Polish press law to date, in order to adapt it to the changed conditions of the publishing press, courts often have to adopt a functional and purposeful interpretation at the expense of a literal translation.
} 
recurrent nature of information provided to the recipients via the website created for this purpose, rather than the regularity of periods between individual publications. The possibility of changing the content of the website many times by updating it does not deprive the website of a periodical nature. ${ }^{40}$ Similarly, a broad understanding of periodicity, as part of the definition of a press publication adopted in Directive 2019/790, will not be necessary because regular updates provide enough grounds to consider such publications as press publications. However, unlike the Polish definition of "press", Directive 2019/790 does not mention the maximum interval between individual issues. It may turn out that press publications, for which publishers will have related rights in the Polish copyright system, will not be "press" within the meaning of the Polish Press Law Act.

The issue of one title under which a press publication is published remains an important element as well. The date, price and other elements, sometimes required in national systems for a publication to meet the definition of press, are inconsequential. In turn, Directive 2019/790 does not require any official registration of the title of a press publication. Therefore, even if a press publisher does not meet the requirements of its national law in this respect, it should be able to enjoy the related rights granted. A uniform title is enough. However, it is debatable whether a link can be considered to be such a title. The link only indicates the location of the site on the network. However, it cannot be ruled out that the link will contain the title of a press publication.

\section{Requirement to Provide Information Related to Current News or Other Topics}

The aim of press publications is to provide the general public with information related to current news or other topics. According to the literature, this premise does not bring any added value due to its open nature. ${ }^{41}$ However, it is probable that everything depends on a certain national perspective on understanding the concepts of the "press" and "press publication" as specific, collective works.

The discussed premise excludes from the category of press publications works containing only advertisements or announcements, as well as comics, cartoons or episodes of a novel, which do not serve informational purposes, but promotional or entertainment purposes. The purpose of a press publication is to disseminate current information. If a given publication only satisfies other needs, it is not a press publication. Hence, the introduction of the target that a press publication must serve is undoubtedly significant, because numerous periodicals can thus be excluded from the scope of what is referred to as a press publication. The Polish legal system does not introduce such a boundary between the press and other periodical publications within the concept of the press. Hence, only by interpreting specific provisions of the Polish Press Law Act can such publications that are exclusively of an advertising

\footnotetext{
40 Judgment of the Supreme Court of 28 October 2016, I CSK 695/15, Orzecznictwo Sądów Polskich (Jurisprudence of the Polish Courts) (2017), No. 12, Sec. 126.

41 Bently and Smith (2016), p. 12.
} 
nature or contain purely fairy tales be excluded from the scope of the concept of the press. $^{42}$

It is also important that, according to Directive 2019/790, the information is expected to be provided to the general public, and therefore to an unspecified number of people. If, potentially, anyone who wants the publication can obtain it after fulfilling formal conditions, the publication is addressed to the public. Recital 56 of Directive 2019/790 expressly states that subscription magazines may be protected by copyright.

It should also be noted that journals published for scientific or academic purposes, such as scientific journals, have been excluded from the scope of press publications covered by Directive 2019/790. Perhaps the reason was that they do not disseminate current information. It also seems that the publishers of such journals cannot strictly shape editorial policy or influence the character of published scientific papers, as the reviewers of these materials submitted for publication play an important role in making decisions on publication. The organization of work in a scientific journal is also not based on journalists as information providers, but on scholars who are independent of the publishers and do not work for them. It should also be noted that a scientific work differs from a work of a journalistic nature. It is also necessary to emphasize the importance of the freedom of science itself, which should not be limited in the editorial process, in contrast to the possibility of restricting the freedom of expression of the journalist by the press publisher.

According to Recital 56 of Directive 2019/790 "periodical publications published for scientific or academic purposes, such as scientific journals, should not be covered by the protection granted to press publications under this Directive". However, neither in the recitals nor in the actual text of Directive 2019/790 is it specified how "periodicals published for scientific purposes" and "periodicals published for academic purposes" should be understood. Furthermore, the EU legislators used the conjunction "or" between the words "scientific" and "academic". This, in turn, may suggest their separate interpretation, especially since the phrase "scientific journals" contained in this recital, as well as Art. 2, point 4, of Directive 2019/790, is for reference only. Perhaps it should be assumed that periodicals published for scientific purposes are those whose goal is to present research and scientific views, and which contain footnotes, articles and bibliographies. It also seems that even if scientific journals include journalistic or promotional materials, but their main content is material of a scientific nature, they will still be considered scientific journals.

On the other hand, the interpretation of the expression "periodicals published for academic purposes" may cause practical interpretation problems in various European Union countries. In English, scientific journals are called "academic or scholarly journals", and are therefore those that present only scientific work. It should be noted, however, that within the types of press there is also the academic press genre. An academic magazine is one that is addressed to the academic community and which does not contain scientific works, but current information about academic life, events relevant to the university, describing the successes of

$\overline{42}$ See Czarny-Drożdżejko (2013), p. 90 et seq. 
scientists and the awards they receive. The publishers of such academic magazines are usually the universities themselves, but also student councils and even independent publishers.

Therefore, there are doubts as to the justification for excluding them from the category of press publications for which related rights have been granted. This approach is understandable for scientific journals, which usually contain scientific articles that are not of a journalistic nature. In turn, there is no justification for excluding from the scope of press publications academic magazines that contain materials of a journalistic nature. In connection with the above, the interpretation of the phrase "periodicals published for scientific or academic purposes" should arguably only include those that are scientific in nature.

\section{Requirement of Editorial Control in the Definition of a Press Publication}

The last necessary requirement for the press publication is that it should be published in any medium, at the initiative of the service provider, under his responsibility and control. This requirement is rightly blamed for not making a reference to the publisher or news agency but generally to the service provider. ${ }^{43}$ Finally, after the changes related to the definition of the subject-matter of this related right were introduced, it should be assumed that said requirement should refer to the publisher or news agency, and not to every service provider. Nevertheless, due to the lack of a definition of a press publisher and news agency, as well as the lack of a definition of the scope of necessary responsibility and control in the context of a press publication, there will be doubts related to the implementation of this requirement, which will have to be resolved by national courts and by the CJEU. $^{44}$

In Recital 56 of Directive 2019/790 it was stated that protection granted to press publications should not "apply to websites, such as blogs, that provide information as part of an activity that is not carried out under the initiative, editorial responsibility and control of a service provider, such as a news publisher". There is no doubt that numerous websites consist of various works and can be collections of works themselves. The exclusion provided for in Directive 2019/790 was introduced exactly because of the absence of control over the entire publishing process, on the basis of which the material undergoes suitability for publication. Hence, it would seem appropriate that those websites, in which the publisher is the same person as the author of the majority of works communicated to the public, even if such person set up a so-called "publishing company", should be excluded from the scope of press publications. In a press publishing house an independent control system and editorial board must exist. The principle regarding the press publication must be that communications come from the community and are addressed to the community, enabling a mass, and not individual, communication process. The literature ${ }^{45}$

\footnotetext{
43 Bently and Smith (2016), pp. 12-13.

44 See van Eechoud (2017), p. 35.

45 Bently and Smith (2016), p. 9.
} 
emphasizes that collections that do not contain journalistic works, such as match schedules or timetables, are excluded from the category of press publications. The journalistic nature of the works included in the concept of press publication has the task of limiting the scope of the term "press publication", and thus the scope of exclusive rights granted to publishers and news agencies.

However, it should be noted that this requirement does not exclude from the category of press publications any websites of different companies whose press offices publish diverse types of information about their activities, for example, concerning sports or new technologies, which provide current information and - via press publications - address the public. Also, various newsletters sent by entities engaged mainly in activities other than publishing are not excluded. They can, for example, relate to current case-law or information about law provisions in force, which are usually of interest to the public and have the attribute of novelty, but may also refer to hybrid varnishes and novelties in their use. In such cases, editorial control and liability of the service provider may come into play as well. The CJEU will have to face the problem of qualifying such borderline publications.

\section{Conclusion}

In summary, it will be the CJEU that will have to cope with the problems of the analysis of the definition of press publications.

It should be noted that in the respective Member States the notions "press publication" or "press" as such do not only refer to the questions covered by the scope of application of the discussed Directive 2019/790 but also to various other regulations that may be beyond any competence of the European Union. This may lead to a different understanding of the terms "press publication" or "press" since the purposes of various areas or branches of the law differ. On the one hand, this contradicts the principles of legal interpretation. On the other hand, imposing a uniform definition of a "press publication" or "press" on the Member States, also in the areas that do not fall within the scope of EU coordination, would seem unacceptable. In conclusion, only in a few years will we be able to see whether the discussed regulation will bring the desired effect, and will thus increase the income of publishers and journalists in respect of the published press materials.

Open Access This article is licensed under a Creative Commons Attribution 4.0 International License, which permits use, sharing, adaptation, distribution and reproduction in any medium or format, as long as you give appropriate credit to the original author(s) and the source, provide a link to the Creative Commons licence, and indicate if changes were made. The images or other third party material in this article are included in the article's Creative Commons licence, unless indicated otherwise in a credit line to the material. If material is not included in the article's Creative Commons licence and your intended use is not permitted by statutory regulation or exceeds the permitted use, you will need to obtain permission directly from the copyright holder. To view a copy of this licence, visit http:// creativecommons.org/licenses/by/4.0/. 


\section{References}

Barta J, Markiewicz R (2013) Prawo autorskie. Wolters Kluwer, Warsaw

Bently L, Smith H (2016) Call for views: modernising the European copyright framework. https:// microsites.bournemouth.ac.uk/cippm/files/2017/01/

IPOModernisingIPProfResponsePressPublishers.pdf. Accessed 18 Nov 2018

Blin H, Chavanne A, Drago R (1969) Traité du droit de la presse. Librairies Techniques

Czarny-Drożdżejko E (2013) Przestępstwa prasowe. Francuska regulacja dotycząca przestępstw prasowych i jej odniesienie do polskiego systemu prawnego. Wolters Kluwer, Warsaw

Czarny-Drożdżejko E (2016) Dozwolony użytek utworów w mediach. Difin, Warsaw

Debbasch C, Isar H, Agostinelli X (2002) Droit de la communication audiovisuel, presse, internet. Dalloz, Paris

Dobosz I (2011) Prawo prasowe. Wolters Kluwer, Warsaw

Michalski B (1972) Przedruk prasowy w świetle prawa. Ośrodek Badań Prasoznawczych RSW Prasa, Cracow

Rapport sur l'objet et le champ d'application du droit voisin des éditeurs de publications de presse (2018). https://www.editionmultimedia.fr/wp-content/uploads/2018/05/Rapport-CSPLA-sur-le-droit-voisindes-éditeurs-de-presse-Février-2018. Accessed 25 Nov 2018

Ricketson S, Ginsburg JC (2006) International copyright and neighbouring rights. The Berne convention and beyond, vol 1. OUP, Oxford

van Eechoud M (2017) A publisher's intellectual property right. Implications for freedom of expression, authors and open content policies. https://www.openforumeurope.org/wp-content/uploads/2017/01/ OFE-Academic-Paper-Implications-of-publishers-right_FINAL.pdf. Accessed 20 Nov 2018

Vivant M, Bruguière JM (2015) Droit d'auteur et droits voisins. Dalloz, Paris

Wolny-Zmorzyński K, Kaliszewski A (2014) Rodzaje i gatunki dziennikarskie. Próba ustaleń genologicznych. In: Wolny-Zmorzyński K, Kaliszewski A, Snopek J, Furman W (eds) Prasowe gatunki dziennikarskie. Poltext, Warsaw

Zoll F (1926) Polska ustawa o prawie autorskim i Konwencja Berneńska. Gebethner and Wolff, Warsaw

Publisher's Note Springer Nature remains neutral with regard to jurisdictional claims in published maps and institutional affiliations. 